Original Article

\title{
Growth regulators and their reflection on different hop genotypes cultivated under in vitro conditions
}

\author{
Reguladores de crescimento e seu reflexo em diferentes genótipos de lúpulo \\ cultivados in vitro

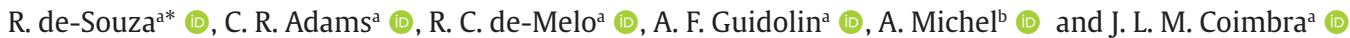 \\ a Universidade do Estado de Santa Catarina - UDESC, Centro de Ciências Agroveterinárias - CAV, Instituto de Melhoramento e Genética Molecular - \\ IMEGEM, Departamento de Agronomia, Programa de Pós-graduação em Produção Vegetal, Lages, SC, Brasil \\ ${ }^{\mathrm{b}}$ Instituto Federal de Educação, Ciência e Tecnologia do Rio Grande do Sul - IFRS, Laboratório de Cultura de Tecidos e Citogenética Vegetal, Sertão, RS, Brasil
}

\begin{abstract}
Hops is a new culture in Brazil. Tissue culture can be an important technique for rapid hop propagation. This paper aims to characterize responses from different genotypes under different growth regulators through the interrelationship of response variables important to hop in vitro growth. Three genotypes were cultivated in six culture media with different combinations of growth regulators, BAP (6-benzylaminopurine), IAA (3-indolacetic acid) and $\mathrm{GA}_{3}$ (gibberellic acid). The means were compared by orthogonal contrasts and the interrelationship of the response variables was performed by path analysis. American genotypes showed favorable root development under the BAP + IAA combination, while the use of IAA improved shoot development. The origin of genotypes was important for defining the best protocol for in vitro cultivation. The path coefficient showed that the variable number of shoots has stronger direct effect on the number of nodal segments. Additionally, in tissue culture assays, the use of a covariable and proper error distribution significantly increased experimental accuracy.
\end{abstract}

Keywords: H. lupulus, tissue culture, genetic breeding, european and american origin.

\begin{abstract}
Resumo
O lúpulo é uma nova cultura no Brasil. A cultura de tecidos pode ser uma técnica importante para a propagação rápida do lúpulo. Este artigo tem como objetivo caracterizar respostas de diferentes genótipos sob diferentes reguladores de crescimento através da inter-relação de variáveis de resposta importantes para o crescimento in vitro. Três genótipos foram cultivados em seis meios de cultura com diferentes combinações de reguladores de crescimento, BAP (6-benzilaminopurina), AIA (ácido 3-indolacético) e GA3 (ácido giberélico). As médias foram comparadas por contrastes ortogonais e a inter-relação das variáveis de resposta foi realizada por análise de trilha. Os genótipos americanos apresentaram desenvolvimento radicular favorável sob a combinação BAP + AIA, enquanto o uso do AIA melhorou o desenvolvimento da parte aérea. A origem dos genótipos foi importante para definir o melhor protocolo para o cultivo in vitro. $O$ coeficiente de trilha mostrou que a variável número de brotos tem um efeito direto mais forte no número de segmentos nodais. Adicionalmente, em experimentos com cultura de tecidos, o uso de uma covariável e distribuição de erro adequada aumentou significativamente a precisão experimental.
\end{abstract}

Palavras-chave: H. lupulus, cultura de tecidos, melhoramento genético, origem europeia e americana.

\section{Introduction}

Hops (Humulus lupulus L.) is a perennial, dioecious, climbing-growing plant from the Cannabaceae family. Only female plants produce the cone, a structure that gives rise to a substance called lupulin. It is mainly used in the production of beer, due to its organoleptic and antibacterial properties that increase beer foam stability. It is also used in the manufacture of drugs, mainly as a natural tranquilizer. Brazil is ranked as the third largest beer producer in the world. However, all the hops used in the production of Brazilian beer are imported. The total volume is about 3,500 tons per year, with an annual cost close to US \$ 60 million (Brasil, 2019a).

The great interest in hop culture in Brazil is due to the growing demand, since the number of craft breweries has increased in the country (Brasil, 2019b). Brazil is not selfsufficient in hop production, but has the potential for it. Besides, the yield per hectare can reach US\$70.000, since a single hop plant produces on average one kilo of cones, whose price ranges from US\$50 to US\$100. Therefore, this is a highly profitable activity. Hop seedlings are currently

*e-mail: rubia75@live.com

Received: August 22, 2020 - Accepted: December 5, 2020 
traded at an average price of US\$ 15 , which is considered expensive, compared to other fruit, such as apple, whose seedling unit average price is US\$3. Thus, micropropagation is an alternative to reduce the cost of seedlings, and consequently, the cost of a hop garden implantation.

Due to hop economic relevance, in vitro cultivation is one of the most viable alternatives for mass production of seedlings, since the propagation of the species is predominantly asexual for commercial purposes (rhizomes or rooting nodal cuttings) (Silveira et al., 2016). The quality of the seedlings used in the establishment of a hop garden directly affects crop yield. There are numerous difficulties involving multiplication via rhizomes and cuttings. Multiplication by the methods only occurs in the spring, which marks the beginning of hop sprouting, in addition to facilitating the spread of systemic fungi, bacteria and viruses, a phenomenon that decreases product quality and crop yield.

In tissue culture, in addition to the different responses obtained between species, variation between genotypes are usually reported. However, the most studies with the hop are based only a single genotype (Machado et al., 2018; Peredo et al., 2006; Roy et al., 2001). To be successful in the micropropagation technique, we must study the behavior of hop genotypes. Some genotypes may, for example, not need growth regulators for rooting. This information could reduce costs in preparing the culture medium, labor, especially in laboratories that produce seedlings on a large scale. In addition, we are also unaware of studies evaluating the in vitro development of hop genotypes of different origins (american and european, for example). These are two groups representing the cultivation of hops, and we do not know whether the responses of the genotypes are the same or different within the same group.

Among other advantages of in vitro culture are that it can be widely used in plant breeding to produce genetically identical individuals of high phytosanitary quality. In addition to facilitating the transport and exchange of genotypes, it also enables better control of plant growth conditions and facilitates exposure of a large number of plants to mutagenic agents (which promotes genetic variability). However, the selection of the appropriate culture medium to grow a certain species or cultivar can be considered one of the most important factors in seedling development. The culture medium supplies plant tissues with water, macro and micronutrients and organic products (such as growth regulators) necessary for explant development under in vitro culture conditions. However, some species (and their different genotypes) may have greater difficulty in developing in a stressful environment, such as in vitro culture. Thus, the use of growth regulators can allow the development of explants with higher quality. Growth regulators are biomolecules that induce physiological responses, such as roots development, elongation of internodes, bud induction and fruiting (Barrueto-Cid, 2014). The most employed growth regulators are: $i$ ) IAA (auxin), used for callus induction or rooting of sprouts; ii) CIN and BAP(synthetic cytokine), which promote cell division, and induce the sprouting of axillary buds; iii) GA3 (gibberellin), which elongates the shoots or internodes (Taiz et al., 2017; Zimmermann,
2014). These growth regulators can act differently in a given plant species, depending on the doses used and the combinations provided in the culture medium where the explant will be grown.

The adoption of growth regulators contributes to solving the difficulties encountered in in vitro explant regeneration, but the possibilities of combinations between regulators are immense, which leads to a variety of results for the main establishment variables (roots, shoots, calluses). Aware of the many possibilities and difficulties for selecting culture media for in vitro hop cultivation, we propose to characterize the responses from different genotypes under different growth regulators through the interrelationship of response variables important to in vitro hop growth (Humulus lupulus L.).

\section{Material and Methods}

\subsection{Plant material}

The nodal segments of female plants of Humulus lupulus of three genotypes were kept in a greenhouse and used as explants: Hallertauer Mitterlfrüeh (HallertauerM) (European origin), Columbus and Chinook (American origin). After being collected, they were washed in running water for five minutes and sectioned in around $2 \mathrm{~cm}$ long bevel cut, each node with two axillary buds. Subsequently, the explants were taken to the laminar flow chamber for the aseptic procedures.

\subsection{Culture medium}

The base culture medium used was MS (Murashige and Skoog, 1962), added with vitamins, $20 \mathrm{~g} \mathrm{~L}^{-1}$ sucrose, solidified with $8 \mathrm{~g} \mathrm{~L}^{-1}$ agar, with $\mathrm{pH}$ adjusted to 5.8 before autoclaving. The medium was autoclaved for 20 minutes at $121{ }^{\circ} \mathrm{C}$ and then placed in test tubes $(20 \times 200 \mathrm{~mm})$ which were sealed with aluminum foil. Six culture media were tested: M1 (without growth regulators), M2 (BAP + IAA + $\left.\mathrm{GA}_{3}\right), \mathrm{M} 3$ (BAP + IAA), M4 (BAP), M5 (IAA) and M6 (GA $)$, with doses of $1.0 \mathrm{mg} \mathrm{L}^{-1} \mathrm{BAP}, 0.02 \mathrm{mg} \mathrm{L}^{-1} \mathrm{IAA}$ and $0.1 \mathrm{mg} \mathrm{L}^{-1} \mathrm{GA}_{3}$.

\subsection{Asepsis, isolation and incubation}

Sodium hypochlorite ( $2.0 \%$ active chlorine) with Tween 20 (3 drops per $100 \mathrm{ml}$ of solution) was used for explant asepsis. The explants remained in agitation for 15 minutes. They were then washed three times with sterile distilled water and isolated in test tubes containing the culture medium. Then, they were sealed with aluminum foil and covered with transparent plastic film. After isolation, the tubes were kept in an in vitro culture growth chamber, with a photoperiod of 16 hours and a temperature of $24 \pm 2{ }^{\circ} \mathrm{C}$. After 15 days, the explants were evaluated.

\subsection{Statistical analysis}

A completely randomized design was used in a $6 \times 3$ factorial scheme (six culture media and three genotypes). Each treatment consisted of 10 replications, totaling 180 experimental units. Root length $(\mathrm{cm})$, shoot height $(\mathrm{cm})$, number of shoots and number of nodal segments were 
assessed. The data were analyzed by the SAS University Edition software system using the Glimmix procedure, considering the following statistical model (Equation 1):

$$
Y_{i j}=\mu+g_{i}+m_{j}+g_{i j}+e_{i j}
$$

where: " $Y_{i j}$ " is the observed value of the response variable of genotype " $\mathrm{i}$ " in the medium " $\mathrm{j}$ "; " $\mu$ " is the effect associated with the overall mean; " $g$, is the fixed effect genotype " $i$ " $(i=1,2,3)$; " $m_{j}$ " is the fixed effect of the culture medium "j" $(\mathrm{j}=1, \ldots, 6) ;$ " $\mathrm{gm}_{\mathrm{ij}}$ " is the fixed effect of the interaction of the factors medium and genotype; and " $\mathrm{e}_{\mathrm{ij}}$ " refers to the effect of the residue.

Proc Glimmix was used due to the possibility of adjusting the distribution of residues. The response variables had the distribution adjusted by Lognormal $(\rho=\ln )$, with the argument dist $=$ lognormal. Error independence was corrected by adjusting the error variance and covariance matrix (Huynh-Feldt (HF) matrix), and the assumption of variance homogeneity was simultaneously considered.

Graphical dispersion analysis, residue inspection, outlier identification and data transformations were also performed as alternatives to adapt the statistical model. In addition, the variable number of shoots was identified as a $x$ variable (independent) and therefore used as a covariable to aid in the interpretation of results and increase the accuracy of the estimates from the estimators under analysis and the interpretation of the biological data, considering that $x$ was incorporated into the statistical model already described. Improved fit, ie the comparison between the fitted model and the previous model, was verified by the Akaike Information Criterion (AIC). After inspection of the covariance analysis, the degrees of freedom of the interaction were decomposed with the use of the Slice argument for the culture medium factor within each level of the genotype factor. Subsequently, considering a comparison structure between treatments, the culture media was compared through univariate orthogonal contrasts.

To determine the phenotypic correlations and analysis of the path coefficients, four response variables were evaluated. The Genes software system was used for the analysis. The phenotypic correlations were partitioned into direct and indirect effects of the variables root length, shoot height and number of shoots on the number of nodal segments, by the path analysis.

\section{Results and Discussion}

The whole comparison of treatments (whether genotypes and culture media, for example) is strongly related to an adequate statistical model. This model reveals assumptions to be met. In the case of analysis of variance, the assumptions of normality and homogeneity of the residues are widely discussed. However, tissue culture experiments yield difficult-to-model data for both error distribution adjustment and variance homogeneity adjustment. An enormous number of "zeros" are often counted in assessments of experiments, because the organ of interest (root, for example) is not formed, which can be explained by the inhibitory effect of the growth regulator or its absence. This evidence may prevent the assumptions of the statistical model from being met. One of the first alternatives generally adopted by the researcher is the use of transformations, such as Poisson and Logitic (Steel et al., 1997). However, reports of non-compliance with one, two or all assumptions are common, how it happened in this study.

In this sense, in order to properly interpret the biological data, the variables were inspected according to covariance analysis (Table 1). Thus, it was found that the variable number of shoots is an independent variable (the F statistics was not significant for any factors). The use of number of shoots as a covariable together with the adjustment of the lognormal distribution improved the statistical model and interpretation, as well the precision. AIC values was significantly reduced for all adjusted variables. The variable number of nodal segments presented the most significant reduction for AIC when the model was adjusted. The smaller the AIC value, the better the model. The proposed analysis is simple but not often used in tissue culture. This methodology has great potential for routine application to the analysis of laboratory experiments and the achievement of more reliable results.

In addition, it is clear that the calculated $F$ values increased, a fact related to the reduced values of the residual mean squares (Table 1 ). The use of covariance helps control the experimental error and increases the accuracy of treatment comparison, which favor the interpretation of the results (Ramalho et al., 2000). It also allows the elimination of systematic error, which is not controlled by a researcher and may lead to erroneous results and interpretations (Hair et al., 2009). In addition,

Table 1. F values of covariance analysis for the variables root length (RL), shoot height (SH), number of shoots (NS) and number of nodal segments (NNS). Model adjusted by lognormal distribution and covariable insertion (NS), with the exhibition of the analysis with the original variables and with the variables after the adjustment. Considerations made for the three hop genotypes in six culture media.

\begin{tabular}{|c|c|c|c|c|c|c|c|c|c|c|c|c|c|c|c|}
\hline \multirow{2}{*}{$\mathbf{S V}^{1}$} & \multirow{2}{*}{ DF $^{2}$} & \multicolumn{7}{|c|}{ Variables } & & \multicolumn{6}{|c|}{ Adjusted Variables } \\
\hline & & $\mathbf{R L}$ & & SH & & NS & & NNS & & $\mathbf{R L}$ & & SH & & NNS & \\
\hline G & 2 & 4.06 & ${ }^{*}$ & 5.49 & * & 0.45 & ns & 0.18 & ns & 6.29 & $*$ & 6.47 & $*$ & 4.44 & * \\
\hline M & 5 & 2.88 & $*$ & 3.83 & * & 1.00 & ns & 0.56 & ns & 1.00 & ns & 3.54 & $*$ & 1.06 & ns \\
\hline $\mathrm{G}^{*} \mathrm{M}$ & 10 & 1.99 & * & 1.55 & ns & 0.66 & ns & 1.92 & $*$ & 2.53 & $*$ & 2.16 & $*$ & 2.93 & * \\
\hline $\mathrm{AIC}^{3}$ & & 433.72 & & 690.33 & & 610.38 & & 868.08 & & 256.82 & & 356.12 & & 219.19 & \\
\hline
\end{tabular}

${ }^{*}$ Significant at $5 \%$ error probability by the F test. ns: non-significant; ${ }^{1} \mathrm{SV}$ : Sources of variation: G - genotype, M - culture medium; ${ }^{2} \mathrm{DF}$ : number of degrees of freedom; ${ }^{3}$ AIC: Akaike information criterion. 
the variables are positively correlated with the variable number of shoots, so that when one of them increases, the other increases simultaneously.

After the adjustment, the $\mathrm{F}$ test revealed a statistical difference for the interaction of factors in all variables (Table 1). Which indicates dependence between the effects of culture media and genotypes. Thus, this result demands a qualitative description of the interaction. The results indicated that the variations between culture media within the evaluated genotypes were significant (data not shown). Thus, for the variables root length, shoot height and number of nodal segments, the variation between culture media for the evaluated genotypes can be analyzed by contrast estimation (Table 2 ).

Genotypes Chinook and Columbus presented the best root development rates when grown in culture media containing combinations of growth regulators (contrast 2) (Table 2). The balance between hormone classes (mainly auxin and cytokines) controls plant development and defines the organ to be formed (Mercier, 2019). In this case, the $0.02 \mathrm{mg} \mathrm{L}^{-1}$ dose of IAA combined with the $1.0 \mathrm{mg}$ $\mathrm{L}^{-1}$ dose of BAP provided a hormone balance favorable to auxin, which benefits root development for the Chinook and Columbus genotypes. In fact, IAA reveals an effect on rooting, and explant segmentation naturally leads to the accumulation of this hormone in its basal region, since auxin transport follows a polar direction.

The rooting effect can be enhanced by subjecting the tissue to an auxin solution. However, there are limitations regarding the explanation of the effects caused by auxin/ cytokine balance, such as insufficient knowledge about absorption, transport and inactivation capacity of plant tissue, in addition to changes in endogenous hormone levels caused by exogenous hormonal application (Peres and Kerbauy, 2019). Indeed, for the combination of auxin and cytokine to be effective, there must be a balance between them, ie doses that are sufficient to induce the rooting process without causing toxicity to the explant, which would lead to callus formation. The combined use of auxin and cytokine was also favorable to root development in other species, such as $M$. sergipenses (coroa-de-frade) (Bravo Filho et al., 2018). However, the results are not always the same or similar, since the response depends on several other factors, such as explant type and age and nutritional condition of the donor plant. For example, in the cultivation of $A$. rosaeodora (pau-rosa) found better results when they used only auxin (Jardim et al., 2010). On the other hand, the best medium for hop rooting was MS medium plus only $0.1 \mathrm{mg} \mathrm{L}^{-1}$ of BAP (Machado et al., 2018). These results only confirm the true interaction between genotype and culture medium, as it is well known that explant development is involved with both hormonal and genetic factors. On the other hand, the best medium for hop rooting was MS medium plus only $0.1 \mathrm{mg} \mathrm{L}^{-1} \mathrm{BAP}$ (Machado et al., 2018).

Still with respect to Chinook and Columbus genotypes, M5 (IAA) provided good growth of shoots (4.43 and $4.99 \mathrm{~cm}$ ) and number of nodal segments (5.70 and 5.90), with significant difference from M6 $\left(\mathrm{GA}_{3}\right)$, also exceeding the means of isolated use of BAP (contrasts 5 and 3 ) (Table 2). The means of the morphometric variables are shown for a better understanding of the behavior of the genotypes and the respective comparisons (Table 3 ). In tissue culture, the addition of IAA to the culture medium is often aimed at inducing root beginnings, not the growth of aerial parts. This same effect of IAA on shoot growth was also

Table 2. Estimates of contrasts of genotype-attributable effects for each culture medium level for the variables root length (RL), shoot height (SH) and number of nodal segments (NNS) regenerated in in vitro culture.

\begin{tabular}{|c|c|c|c|c|c|c|c|}
\hline Source of variation ${ }^{1}$ & $\mathbf{D F}^{2}$ & $\mathbf{R L}$ & & SH & & NNS & \\
\hline C1: M|Chinook & 1 & -2.19 & ns & -2.49 & ns & 1.26 & ns \\
\hline $\mathrm{C} 1: \mathrm{M} \mid$ Columbus & 1 & 0.27 & ns & -3.24 & $\cdot$ & -1.34 & ns \\
\hline C1: M|HallertauerM & 1 & 2.44 & ns & 0.24 & ns & 0.65 & ns \\
\hline $\mathrm{C} 2$ : M|Chinook & 1 & 0.94 & ns & -0.74 & ns & -0.04 & ns \\
\hline $\mathrm{C} 2: \mathrm{M} \mid$ Columbus & 1 & 1.57 & $*$ & 0.56 & ns & 0.76 & ns \\
\hline C2: M|HallertauerM & 1 & -0.90 & ns & -0.98 & ns & -0.80 & * \\
\hline C3: M|Chinook & 1 & -0.01 & ns & -0.27 & ns & -0.05 & ns \\
\hline C3: M|Columbus & 1 & -0.50 & ns & -0.17 & ns & -0.26 & ns \\
\hline C3: M|HallertauerM & 1 & -0.43 & ns & 0.44 & ns & 0.17 & ns \\
\hline C4: M|Chinook & 1 & 0.09 & ns & 0.43 & ns & 0.31 & ns \\
\hline C4: M|Columbus & 1 & -0.40 & ns & 0.39 & $*$ & 0.14 & ns \\
\hline C4: M|HallertauerM & 1 & -0.08 & ns & 0.26 & ns & 0.05 & ns \\
\hline C5: M|Chinook & 1 & 0.10 & ns & 0.69 & $*$ & 0.36 & $*$ \\
\hline C5: M|Columbus & 1 & 0.10 & ns & 0.57 & $*$ & 0.40 & * \\
\hline C5: M|HallertauerM & 1 & 0.35 & ns & -0.17 & ns & -0.12 & ns \\
\hline
\end{tabular}

${ }^{*}$ Significant at 5\% probability by the F test. ns: non-significant; ${ }^{1} \mathrm{C} 1$ : M1 vs. M2, M3, M4, M5, M6; C2: M2, M3 vs. M4, M5, M6; C3: M4 vs. M5; C4: M4 vs. M6; C5: M5 vs. M6. M1 (absence of growth regulators), M2 (BAP+IAA+GA3), M3 (BAP+IAA), M4 (BAP), M5 (IAA) e M6 (GA3), with doses of $1.0 \mathrm{mg} \mathrm{L}^{-1}$ of BAP, $0.02 \mathrm{mg} \mathrm{L}^{-1}$ of IAA and $0.1 \mathrm{mg} \mathrm{L}^{-1}$ of GA3; ${ }^{2} \mathrm{DF}$ : number of degrees of freedom. 
reported in in vitro cultivation of pineapple (Barboza and Caldas, 2001), thyme (Rubin et al., 2007) and peppermint (Morais et al., 2014), which indicates that, when added at low doses, it may favor the elongation of shoots of some species. This fact can be explained by the acidification in the cell wall caused by auxin, which induces cell wall loosening and greater water and potassium absorption and consequent cell expansion. Auxin acts as a signaler for cell division, stretching and differentiation, and plays an important role in apical dominance. In addition, the segmentation of shoots and the consequent breakdown of apical dominance in plants causes auxin (which follows its flow from the apex to the base of the plant) to be supplied at lower concentrations, thus releasing the axillary bud of the inhibition under development. Thus, the height of the shoots and the number of nodal segments are increased. Tissue culture often uses this technique, growing tiny nodal segments, under in vitro conditions, with side buds that become a complete plant within few days (Mercier, 2019).

This result obtained for shoot height and number of nodal segments is fundamental in tissue culture. The number of nodal segments is an important variable for hop micropropagation, as well as for other crops, such as potatoes, strawberries and orchids. The nodal segment is the explant type most widely used for plant multiplication. Each nodal segment of a hop plant has a knot with two buds, which will give rise to new shoots. Therefore, multiplication becomes exponential, and the more nodal segments, the greater the number of new plants (Figure 1). In addition, the nodal segment is an explant with lower chances of occurrence of somaclonal variation, since seedling regeneration usually occurs without the callus intermediate phase, which preserves genetic fidelity.

In general, it is observed that M1 caused low average shoot growth for the three genotypes (Chinook: $2.22 \mathrm{~cm}$, Columbus: $2.38 \mathrm{~cm}$ and HallertauerM: $2.70 \mathrm{~cm}$ ) (Table 2). These results are in contrast to those of Machado et al. (2018), in which the medium without the addition of phytohormones presented the highest average for hop sprout height. The endogenous phytohormone concentration of the evaluated genotypes is possibly insufficient to stimulate the growth of the formed shoots, since there was poor M1 performance for the three genotypes, which demonstrates that the in vitro explant development depends on the interaction and balance between endogenous and exogenous phytohormones of the explant.

HallertauerM genotype presented no significant differences for root length and shoot height, regardless of the culture medium used, but presented the highest average for root length $(1.48 \mathrm{~cm})$ when cultivated in M1, while the highest average for shoot height $(2.90 \mathrm{~cm})$ was obtained when cultivated in M4 (BAP) and the largest number of nodal segments (7.60), when grown in M6 $\left(\mathrm{GA}_{3}\right)$ (Table 2).

Table 3. Original means ( $\mathrm{m}$ ) and standard deviation (sd) of each genotype (HallertauerM., Chinook and Columbus) and medium (M1, M2, M3, M4, M5 and M6) for the variables root length $(\mathrm{cm})$, shoot height $(\mathrm{cm})$ and number of nodal segments regenerated in in vitro culture.

\begin{tabular}{|c|c|c|c|c|c|c|c|}
\hline \multirow{3}{*}{ Medium } & & \multicolumn{6}{|c|}{ Genotype } \\
\hline & & \multicolumn{2}{|c|}{ HallertauerM. } & \multicolumn{2}{|c|}{ Chinook } & \multicolumn{2}{|c|}{ Columbus } \\
\hline & & m & sd & m & sd & m & sd \\
\hline M1 & \multirow{6}{*}{ Root Length } & 1.48 & 1.55 & 0.67 & 0.58 & 0.75 & 0.56 \\
\hline M2 & & 0.31 & 0.64 & 0.86 & 1.05 & 0.57 & 0.56 \\
\hline M3 & & 0.80 & 0.76 & 1.56 & 1.16 & 1.04 & 0.40 \\
\hline M4 & & 0.52 & 0.77 & 1.41 & 0.77 & 0.47 & 0.77 \\
\hline M5 & & 1.99 & 2.15 & 0.99 & 0.44 & 0.65 & 0.36 \\
\hline M6 & & 0.79 & 0.98 & 0.40 & 0.55 & 0.48 & 0.60 \\
\hline M1 & \multirow{6}{*}{ Shoot Height } & 2.70 & 2.08 & 2.22 & 1.38 & 2.38 & 1.64 \\
\hline M2 & & 1.91 & 1.38 & 2.05 & 0.99 & 4.72 & 2.97 \\
\hline M3 & & 2.12 & 1.30 & 4.44 & 3.41 & 3.85 & 1.17 \\
\hline M4 & & 3.38 & 1.79 & 3.60 & 1.32 & 3.31 & 1.64 \\
\hline M5 & & 2.90 & 2.28 & 4.43 & 1.39 & 4.99 & 2.82 \\
\hline M6 & & 2.27 & 1.00 & 2.59 & 0.98 & 2.70 & 1.43 \\
\hline M1 & \multirow{6}{*}{$\begin{array}{c}\text { Number of Nodal } \\
\text { Segments }\end{array}$} & 5.20 & 2.04 & 5.30 & 3.16 & 5.10 & 2.23 \\
\hline M2 & & 3.30 & 1.95 & 5.10 & 2.51 & 5.20 & 2.38 \\
\hline M3 & & 4.80 & 2.30 & 6.20 & 3.85 & 5.70 & 2.54 \\
\hline M4 & & 6.20 & 2.66 & 7.70 & 3.97 & 4.60 & 3.10 \\
\hline M5 & & 5.90 & 4.46 & 5.70 & 1.57 & 5.90 & 1.91 \\
\hline M6 & & 7.60 & 4.45 & 5.00 & 2.87 & 5.10 & 3.90 \\
\hline
\end{tabular}




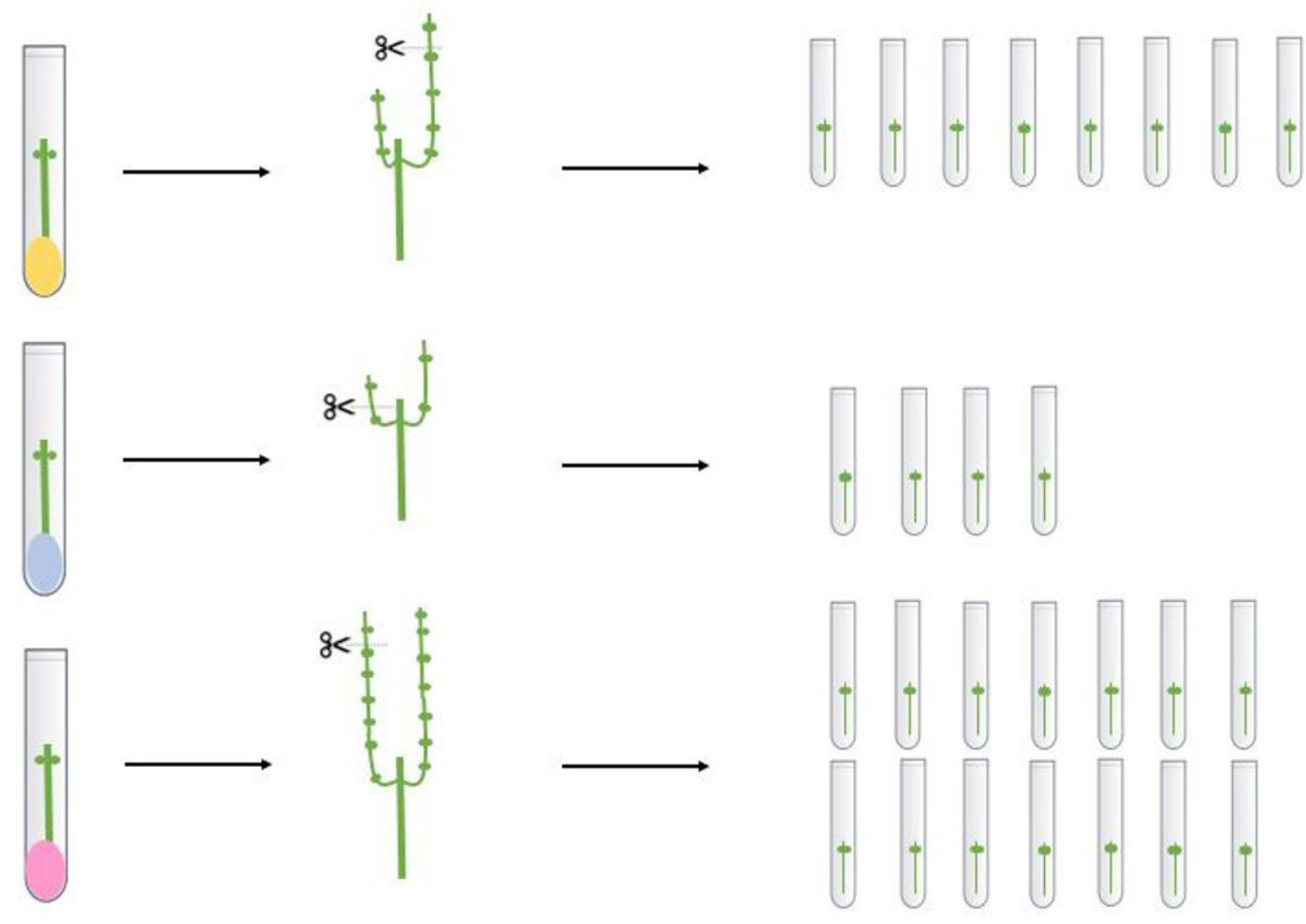

Figure 1. Explants of a hop genotype, grown in different culture media (yellow, blue and pink). Each medium provided different development behavior for the number of nodal segments. The larger the number of nodal segments, the more new plants will be obtained.

Although no significant differences were observed for HallertauerM genotype for the variables root length and shoot height, the media $\mathrm{M} 2\left(\mathrm{BAP}+\mathrm{IAA}+\mathrm{GA}_{3}\right)$ and $\mathrm{M} 3$ (BAP+IAA) significantly reduced the number of nodal segments, and limited root development and shoot growth when compared to the isolated use of growth regulators (contrast 2) (Table 2). The exposure of HallertauerM genotype explants to culture media with more than one growth regulator may have been excessive when added to the endogenous phytohormonium levels, causing an unfavorable hormonal balance and reducing their in vitro development. It must be highlighted that the M2 $\left(\mathrm{BAP}+\mathrm{IAA}+\mathrm{GA}_{3}\right)$ culture medium induced callus formation in $27 \%$ of the explanted cultivated, regardless of the genotype. Excess growth regulators in the culture medium can cause explant toxicity, leading to rapid and excessive cell division and consequent callus formation.

It is important to mention that it was possible to identify the culture media most favorable to the in vitro development of the genotypes Chinook and Columbus and distinct media for the HallertauerM genotype, according to the desired variable (Table 1 ), since, as already stated, the genotype $\mathrm{x}$ culture medium interaction was significant for all adjusted response variables (Table 1). Admittedly, explant development is directly linked to genetic factors. The similarity in the development of Chinook and Columbus genotypes can be explained by the fact that both are American, while HallertauerM comes from Europe.

This variation in the origin of the genotypes is essential for genetic breeding. The genetic and morphological differences found between genotypes are part of the evolutionary process and domestication of species, perceived by changes in human behavior, which are directly related to the development of agriculture (Sereno et al., 2008). The Mediterranean Region is considered the center of origin and diversity of the species, and the plant was first recorded in Europe (Loskutov, 1999). The culture was brought to North America by European settlers. Since then, Americans have released countless and increasingly productive varieties of hops. HallertauerM genotype was not significantly favored by the culture medium, which may be related to its adaptability, as observed in wild hop plants. On the other hand, genotypes of American origin, which have gone through various selection processes to increase productivity (but holding a narrow genetic base), have limitations to adapt and develop well in any environment, which makes them more nutrient-demanding. Thus, genotypes of American origin are less efficient in the synthesis of phytohormones when compared to genotypes of European origin, which favors their development under in vitro conditions, when these elements (growth regulators) are readily available for absorption and at optimal concentration. 


$\begin{array}{ccc}\text { Direct Effect } & \text { Indirect Effect } & \begin{array}{c}\text { Correlation } \\ \text { Coefficient } \\ \left(\mathrm{P}_{\mathrm{i}}\right)\end{array} \\ & \left(\mathrm{P}_{\mathrm{i}}, \mathrm{r}_{\mathrm{i}}\right) & \left(\mathrm{riy}_{\mathrm{i}}\right)\end{array}$

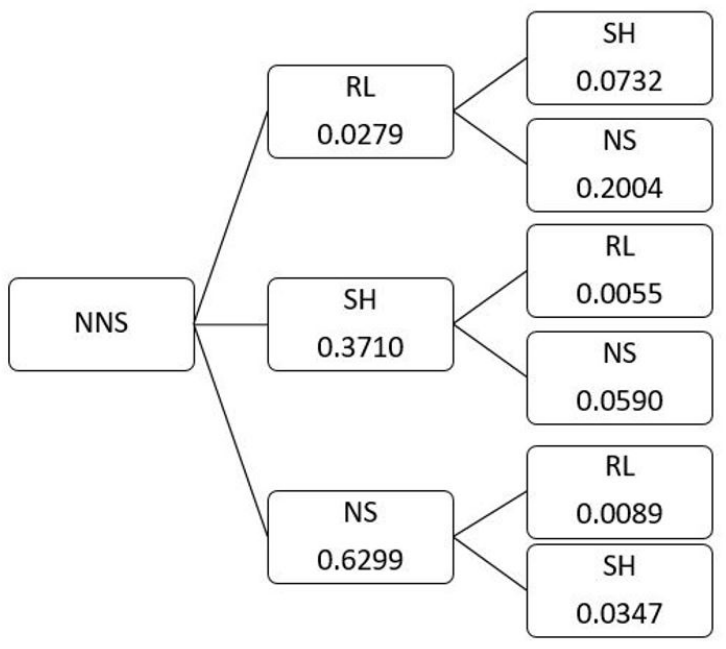

0.3016

0.4355

0.6735

Figure 2. Estimates of the direct and indirect effects of the variables root length (RL), shoot height (SH) and number of shoots (NS) on the variable number of nodal segments (NNS) (main variable).

A path analysis was performed (Figure 2) to improve knowledge about the interrelationship of the response variables evaluated in hop in vitro growth. The variables $\mathrm{RL}$, SH and NS were positively associated with the variable number of nodal segments. However, only the correlation between response variables does not allow us to make conclusions about the cause-effect study, since it is a measure of association. The cause-effect investigation is performed through the path coefficients, that is, the partition of the correlation into direct and indirect effects. The estimates of the direct and indirect effects of the variables RL, SH, and NS on the variable NNS are shown in Figure 1. The sum of the direct and indirect effects results in the correlation coefficient. The variables NS and $\mathrm{SH}$ showed the highest direct effects, the highest correlation coefficients and low indirect effects with NNS. The variable NS revealed a high correlation coefficient (0.6735) and high direct effect (0.6299), which indicates that the truncated selection of this variable can provide satisfactory gains for the variable NNS. The RL variable presented the lowest correlation coefficient $(0.3016)$ and the lowest direct effect (0.0279). Thus, the selection of this variable can provide unsatisfactory gains for the variable NNS. This fact is probably due to the indirect effect via NS (0.2004), which accounts for approximately $66 \%$ of the direct effect of the variable RL with NNS. The variables NS and $\mathrm{SH}$, with high positive correlation with the variable NNS and direct effect in the same direction, indicate the occurrence of cause-effect, that is, these are the main variables that determine the change in the variable NNS. This fact reveals that direct selection over the variable NS will be efficient to increase NNS.

\section{Conclusion}

It is concluded that the application of an appropriate response variable distribution and the use of covariables to improve the model can be considered as an alternative for significant improvement of experimental data in tissue culture. For the genotypes of American origin, Chinook and Columbus, the combined use of IAA $\left(0.02 \mathrm{mg} \mathrm{L}^{-1}\right)$ and $\mathrm{BAP}\left(1.0 \mathrm{mg} \mathrm{L}^{-1}\right)$ provided the best root development, while the use of IAA $\left(0.02 \mathrm{mg} \mathrm{L}^{-1}\right)$ alone caused the best performance for shoot height and number of nodal segments. On the other hand, the in vitro development of the genotype HallertauerM was disadvantaged when grown in combinations of the growth regulators previously studied. The variable number of shoots is highly correlated and has a high direct effect on the number of nodal segments. Thus, the selection of this variable can indirectly select the number of nodal segments, which is very important in the in vitro multiplication of clones.

\section{Acknowledgements}

We are grateful to the Universidade do Estado de Santa Catarina (UDESC, Brasil), Conselho Nacional de Desenvolvimento Científico e Tecnológico (CNPq), Coordenação de Aperfeiçoamento de Pessoal de Nível Superior (CAPES) and Fundação de Apoio à Pesquisa Científica e Tecnológica do Estado de Santa Catarina (FAPESC) for the scholarship granting and the financial support for the conductance of the present work. 


\section{References}

BARBOZA, S.B.S.C. and CALDAS, L.S., 2001. Estiolamento e regeneração na multiplicação in vitro do abacaxizeiro híbrido PE x SC-52. Pesquisa Agropecuária Brasileira, vol. 52, no. 3, pp. 417-423. http://dx.doi.org/10.1590/S0100-204X2001000300004.

BARRUETO-CID, L.P., 2014. Explante, meio nutritivo, luz e temperatura. In: L.P. BARRUETO-CID, ed. Cultivo in vitro de plantas. Brasília: Embrapa, pp. 17-51.

BRASIL. Companhia Nacional de Abastecimento - CONAB, 2019a. Portal de informações agropecuárias. Brasília.

BRASIL. Ministério da Agricultura, Pecuária e Abastecimento MAPA, 2019b. A cada dois dias uma nova cervejaria abre as portas no Brasil. Brasília, $2 \mathrm{p}$.

BRAVO-FILHO, E.S., SANTANA, M.C., PAULO, A.A.S. and ADAUTO, S.R., 2018. Multiplicação in vitro e aclimatização de Melocactus sergipensis. Lilloa, vol. 55, no. 1, pp. 26-36. http://dx.doi org $/ 10.30550 /$ j.lil/2018.55.1/3.

HAIR, J.F.J., BLACK, W.C., BABIN, B.J., ANDERSON, R.E. and TATHAM, R.L., 2009. Análise multivariada de dados. 6. ed. São Paulo: Bookmam, 688 p.

JARDIM, L.S., SAMPAIO, P., COSTA, S.S., GONÇALVES, C.Q.B. and BRANDÃO, H.L.M., 2010. Efeito de diferentes reguladores de crescimento na regeneração in vitro de pau-rosa (Aniba rosaeodora Ducke). Acta Amazonica, vol. 40, no. 2, pp. 275-279. http://dx.doi.org/10.1590/S0044-59672010000200005.

LOSKUTOV, I.G., 1999. Vavilov and his institute: a history of the world collection of plant genetic resources in Russia. Rome: International Plant Generic Resources Institute, 188 p.

MACHADO, M.P., GOMES, E.N., FRANCISCO, F., BERNERT, A.F., BESPALHOK FILHO, J.C. and DESCHAMPS, C., 2018. Micropropagation and establishment of Humulus lupulus $\mathrm{L}$. plantlets under field conditions at southern Brazil. The Journal of Agricultural Science, vol. 10, no. 7, pp. 275-281. http://dx.doi. org/10.5539/jas.v10n7p275

MERCIER, H., 2019. Auxinas. In: G.B. KERBAUY, ed. Fisiologia vegetal. Rio de Janeiro: Guanabara Koogan, pp. 175-198.

MORAIS, T.P., ASMAR, S.A. and LUZ, J.M.Q., 2014. Reguladores de crescimento vegetal no cultivo in vitro de Mentha $\mathrm{x}$ Piperita $\mathrm{L}$. Revista Brasileira de Plantas Medicinais, vol. 16, no. 2, suppl. 1, pp. 350-355. http://dx.doi.org/10.1590/1983-084X/13_017.
MURASHIGE, T. and SKOOG, F., 1962. A revised medium for rapid growth and biossays with tobacco tissue cultures. Physiologia Plantarum, vol. 15, no. 3, pp. 474-497. http://dx.doi. org/10.1111/j.1399-3054.1962.tb08052.x.

PEREDO, E.L., ÁNGELES-REVILLA, M. and ARROYO-GARCÍA, R., 2006. Assessment of genetic and epigenetic variation in hop plants regenerated from sequential subcultures of organogenic calli. Journal of Plant Physiology, vol. 163, no. 10, pp. 1071-1079. http://dx.doi.org/10.1016/j.jplph.2005.09.010. PMid:16971217.

PERES, L.E.P. and KERBAUY, G.B. 2019. Citocinina. In: G.B. KERBAUY, ed. Fisiologia vegetal. Rio de Janeiro: Guanabara Koogan, pp. 199-220.

RAMALHO, M.A.P., FERREIRA, D.F. and OLIVEIRA, A.C., 2000. Experimentação em genética e melhoramento de plantas. 1. ed. Lavras: UFLA, $326 \mathrm{p}$.

ROY, A.T., LEGGETT, G. and KOUTOULIS, A., 2001. Development of a Shoot Multiplication System for Hop (Humulus lupulus L. ). In Vitro Cellular E Developmental Biology. Plant, vol. 37, no. 1, pp. 79-83. http://dx.doi.org/10.1007/s11627-001-0015-0.

RUBIN, S., LIMA, C.S.M., BANDEIRA, J.M., RIBEIRO, M.V., BENITZ, L.C., PETERS, J.A. and BRAGA, E.J.B., 2007. Reguladores de crescimento na multiplicação in vitro de Thymus vulgaris L. Revista Brasileira de Biociências, vol. 5, pp. 480-482.

SERENO, M.J.C.M., WIETHÖLTER, P. and TERRA, T.F., 2008. Domesticação das plantas. In: R.L. BARBIERI and E.R.T. STUMPF, eds. Origem e evolução de plantas cultivadas. Brasília: Embrapa, pp. 37-58.

SILVEIRA, S.S., CORDEIRO-SILVA, R., DEGENHARDT-GOLDBACH, J. and QUOIRIN, M., 2016. Micropropagation of Calophyllum Brasiliense (Cambess.) from nodal segments. Brazilian Journal of Biology = Revista Brasileira de Biologia, vol. 76, no. 3, pp. 656-663. http://dx.doi.org/10.1590/1519-6984.23714. PMid:27143061.

STEEL, R.G.D., TORRIE, J.H. and DIKEY, D.A., 1997. Principles and procedures of statistics: a biometrical approach. 3rd ed. New York: McGraw-Hill, 666 p.

TAIZ, L., ZEIGER, E., MOLLER, I.M.A.X. and MURPHY, A., 2017. Fisiologia e desenvolvimento vegetal. 6. ed. Porto Alegre: Artmed, 858 p.

ZIMMERMANN, M.J., 2014. Embriogêne. In: L.P. BARRUETO-CID, ed. Cultivo in vitro de plantas. Brasília: Embrapa, pp. 69-104. 